\title{
Investigation of performance properties of novel composite fire-extinguishing powders based on mineral raw materials
}

\author{
L. Gurchumelia, G. Bezarashvili, M. Chikhradze \& O. Chudakova \\ G. Tsulukidze Mining Institute, Georgia
}

\begin{abstract}
At present the most efficient fire extinguishers are power ones. Fireextinguishing powders of serial production do not fulfill modern requirements, primarily from the viewpoint of their universal and practical use. It must be noted that most of them contain halogen, and it is established that penetration of halogens into the atmosphere causes a breaking of the ozone layer. The main goal of investigation presented in this paper is development of non-halogen, non toxic, environmentally-friendly, highly-efficient, inexpensive, universal, composite fire-extinguish powders based on domestic mineral raw materials such as clay shale, zeolite and perlite. The proposed method of obtaining composite powders does not require the following expensive chemical processing and modification with halogen-inclusive hydrofobizative additives. Hence, these composite powders will be cheaper (1,5-2 times) than powders of serial production. The raw materials: clay shale, zeolite, perlite were selected according to high operating properties, which are indicative of a reduction of burning processes. The powders must not only be effective during the fire extinguish, but also they must maintain those properties, which decrease the extinguishing effect after small changes in properties. The effectiveness of powders is defined not only according to their dispersity and inhibition ability, but also according to their storage and transportation conditions. These conditions are defined by the exploitation properties of powders. The most important among them are: consolidation and caking, dispersity, tendency of humidity, flow and storage duration. We studied the performance properties of zeolite, perlite and clay shale and composite powders based on such materials and established dependence of tendency to consolidation and caking on dispersity. Accordingly, the dispersity of composite powders was selected in such a way that the tendency of consolidation and caking was minimal. At the same time particle size should be relevant towards the rapid head and destruction, so that we have a homogenous effect and heterogeneous inhibition.
\end{abstract}

Keywords: environmentally friendly, composite fire extinguishing powders, performance properties, tendency of consolidation and caking, dispersity, tendency of humidity. 


\section{Introduction}

In order to receive composite fire-extinguishing powders the following raw materials are chosen: zeolite, clay shale and perlite. Their mineralogical composition presented in table 1 shows that they generally are of silicate origin and contain alkali and alkali-earth metal silicates, carbonates, oxalates; they contain $\mathrm{Fe}, \mathrm{Al}$ and alkali metal hydroxides as admixtures, crystallization water which causes the reduction of burning processes.

Table 1: $\quad$ Chemical containing of mineral materials.

\begin{tabular}{|l|c|c|c|c|c|c|c|c|c|c|c|}
\hline \multirow{2}{*}{ Materials } & \multicolumn{10}{|c|}{ Main components $(\%)$} \\
\cline { 2 - 13 } & $\mathrm{SiO}_{2}$ & $\mathrm{Al}_{2} \mathrm{O}_{3}$ & $\mathrm{Fe}_{2} \mathrm{O}_{3}$ & $\mathrm{FeO}$ & $\mathrm{CaO}$ & $\mathrm{MgO}$ & $\mathrm{CO}_{2}$ & $\mathrm{SO}_{3}$ & $\mathrm{Na}_{2} \mathrm{O}$ & $\mathrm{K}_{2} \mathrm{O}$ & $\mathrm{H}_{2} \mathrm{O}$ \\
\hline Clay shale & 51.2 & 13.60 & 7.40 & - & 8.06 & 3.02 & 10.62 & 0.9 & 3.02 & 2.1 & - \\
\hline Zeolite & 62.9 & 14.45 & 2.32 & 0.51 & 5.67 & 1.32 & - & - & 3.73 & 0.42 & 2.16 \\
\hline Perlite & 73.7 & 12.5 & 6.2 & - & 1.3 & - & - & - & 1.1 & 0.6 & 3.8 \\
\hline
\end{tabular}

On the basis of thermo-gravimetric analysis it has been proved that zeolite, perlite and clay shale are characterized with the extraction of adsorptive and crystallization water and non-burning airs, creation of metal oxides protective film and coke layer. The extracted non-inflammable airs, water vapor and metal oxides in flame zone perform the role of flegmatizator, while in surface zone they cause the production of swelled up layer. The swelled up layer, metal oxides protective film and coke layer create "fire limit" effect, [1].

Fire-extinguishing powders should effectively extinguish fire and for a long time maintain their properties the change of which decreases powder effectiveness. The effectiveness of powder depends not only on inhibition ability but also on the conditions of their storage and transportation. These conditions are determined with powder performance properties the most important being: dispersity, consolidation and caking tendency, moisture content and moistening tendency, fluidity and storage time, $[2,3]$.

The most unfavorable properties of powder are moistening, consolidation and caking which complicate and cause the powder to lose fire-extinguishing ability. There are several methods of reduction of consolidation and caking but all of them are reduced to the decrease of moisture content in powder or the decrease of dispersive particles amount in powder and of contact surface area. Powder drying at high temperature or using of water adsorption admixtures causing powder hydrofobization belong to these methods. For hydrofobization of fireextinguishing powders silicate and fluorine silicate compounds, high dispersive $\mathrm{SiO}_{2}$ modified with chlorsilanes - "aerosile" - are used in serial production powders but it is not universal and its use in most cases is possible in complex with surface active matters, [4-6]. This stipulates that most extinguishing powders of serial production are halogen containing. It is known that penetration 
of halogens into the atmosphere causes a breaking of the ozone layer. Therefore, at present, an elaboration of non-halogen, ecologically friendly fireextinguishing powders is a most important problem. This paper is dedicated mainly to this problem. Proceeding from that requirement we refuse to use the halogen containing additives and selected mineral raw materials: zeolite, perlite and clay shale, which are generally of silicate origin. At the same time, it must be noted that zeolite is characterized with high adsorptive properties and low caking ability; thus zeolite itself acts in composite powders hydrofobizator.

\section{Experimental procedure}

In order to study performance properties of powders laboratory methods are used:

- powder dispersity, $x(\%)$ - granulometric composition, mass concentration of powder remains left on the sieve

$$
x=\frac{m_{1}}{m} \cdot 100
$$

where: $m_{1}$ - mass of powder remains on the sieve, $\mathrm{kg}$;

$m$ - total mass of remains, $\mathrm{kg}$.

- area of powder specific surface $S\left(\mathrm{sm}^{2} / \mathrm{g}\right)$ is determined with the method of air permeability (a standard device “АДП-3" is used) and is calculated with formula;

$$
S=k_{i-j} \frac{A \sqrt{\tau_{i-j}}}{m}
$$

where: $k_{i-j}$ - device constant;

$A$ - the parameter which depends on the height of powder layer $(h)$ and temperature of test $(t)(A=A(h ; t)$;

$\tau_{i-j}$ - time of powder runoff in device column between $i$ and $j$ notches, sec;

$m \quad$ - powder weight mass equal to

$$
m=3.33 p
$$

where: $\rho$ - powder material density, $\mathrm{g} / \mathrm{sm}^{3}$.

- powder fluidity, $Q(\mathrm{~kg} / \mathrm{s})$ - powder mass consumption in time necessary for its dispersion from test fire extinguisher 


$$
Q=\frac{m-m_{\tau}}{\tau}
$$

where: $m$ - mass of extinguisher before testing, $\mathrm{kg}$;

$m_{\tau}$ - mass of extinguisher after testing, $\mathrm{kg}$.

- moisture content and tendency to humidity, $W(\%)$ - the ratio of moist absorbed with powder to powder mass

$$
W=\frac{m_{1}-m}{m} \cdot 100
$$

where: $m_{1}$ - mass of powder remains after moistening, $\mathrm{kg}$;

$m$ - total mass of remains, $\mathrm{kg}$.

- tendency to consolidation and caking, $C(\%)$ - caked mass ratio to powder mass:

$$
C=\frac{m_{c}}{m} \cdot 100
$$

where: $m_{c}$ - mass of formed cakes, $\mathrm{kg}$;

$m$ - powder mass, $\mathrm{kg}$.

It is known the main reason of consolidation and caking is environment humidity and temperature. Powder adsorbs moisture from air, i.e. there happens solid particles solution in condensed water and creation of solid phase saturated solution. With further increase of humidity the solution becomes supersaturated and on contact surface with solid particles there happens solid phase crystallization. Elemental contacts average strength of separate particles depends on structural strength of powder (consolidation and caking), which, in its part, depends on dispersity, setting and consolidation quality of particles, [7, 8]. Thus, for production of fire-extinguishing powders the selection of powder dispersity is to happen with consideration of their performance characteristics.

\section{Results and discussion}

We studied the dependence of consolidation and caking ability on powder dispersity.

Test researches proved that for different powders even in the case of similar dispersity the areas of specific surfaces are distinctly different. As powder caking is caused with solid phase crystallization on contact surfaces of particles, therefore their caking will also differ. With consideration of this we determined specific surface areas for powders of different dispersity and stated the relation of powder caking and specific surface areas, as shown in table 2 and Fig.1. 
Table 2: $\quad$ Performance properties of mineral materials.

\begin{tabular}{|c|c|c|c|c|c|}
\hline Materials & $\begin{array}{c}\text { Powder } \\
\text { dispersity } \\
\text { range, } \\
\text { mm }\end{array}$ & $\begin{array}{c}\text { Area of powder } \\
\text { specific surface, } \\
S\left(\mathrm{sm}^{2} / \mathrm{g}\right)\end{array}$ & $\begin{array}{c}\text { Powder } \\
\text { fluidity, } \\
Q(\mathrm{~kg} / \mathrm{s})\end{array}$ & $\begin{array}{c}\text { Moisture content } \\
\text { and tendency to } \\
\text { humidity, } \\
W(\%)\end{array}$ & $\begin{array}{c}\text { Tendency to } \\
\text { consolidation } \\
\text { and caking, } \\
C(\%)\end{array}$ \\
\hline \multirow{2}{*}{ Clay } & $\mathrm{N} 0.1$ & 7270 & - & 0.17 & 50 \\
shale & $\mathrm{N} 0.1-0.2$ & 5530 & 0.17 & 0.18 & 7.5 \\
& $\mathrm{~N} 0.2-0.3$ & 4530 & 0.17 & 1.2 & 2.0 \\
\hline \multirow{3}{*}{ Zeolite } & $\mathrm{N} 0.1$ & 5530 & - & 3.6 & 25 \\
& $\mathrm{~N} 0.1-0.2$ & 4640 & 0.16 & 4.6 & 0.5 \\
& $\mathrm{~N} 0.2-0.3$ & 4280 & 0.16 & 4.6 & 0 \\
\hline \multirow{3}{*}{ Perlite } & $\mathrm{N} 0.1$ & 2540 & - & 0.7 & 18 \\
& $\mathrm{~N} 0.1-0.2$ & 1295 & 0.14 & 0.7 & 0.3 \\
& $\mathrm{~N} 0.2-0.3$ & 1093 & 0.14 & 0.8 & 0 \\
\hline
\end{tabular}

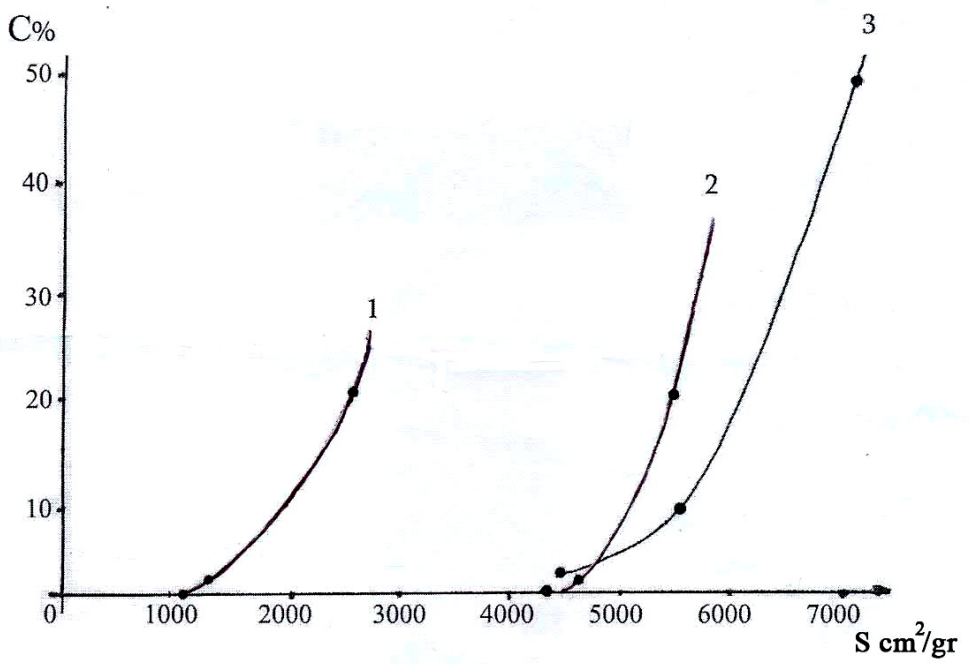

Figure 1: The relation of powder caking and specific surface areas: 1 - zeolite; 2 - perlite; 3 - clay shale.

The analysis of the table and graph data proved that at increase of dispersion in highly dispersive powders caking is distinctly increasing while in lower dispersive powder $(200 \mu-300 \mu)$ at variation of dispersion caking changes negligibly. Thus, for example, in powders dispersed to $100 \mu$ caking is $25-50 \%$. In powders dispersed within $100 \mu-200 \mu$ caking decreases to $1.5-2 \%$, while within $200 \mu-300 \mu$ it drops to $0-0.3 \%$.

Therefore for production of fire-extinguishing powders we chose dispersity $200 \mu-250 \mu$, when the powder will have high performance characteristics: 
(consolidation and caking ability $0.03 \%$ ), powder will be conveniently supplied to the fire site which is indicated powder runoff characteristics (Table 2). At the same time, size of particles will be convenient for their heating and destruction, or homogenic, as well as, heretogenic effect of fire-extinguishing will take place.

We studied test data of exploitation characteristics of clay shale, zeolite, perlite and their composite powders of $200 \mu-250 \mu$ dispersity. Test results are given in table 3.

Table 3: $\quad$ Performance properties of powders and composite powders.

\begin{tabular}{|c|c|c|c|c|}
\hline Powders & $\begin{array}{c}\text { Powder } \\
\text { dispersity, } \\
X(\%)\end{array}$ & $\begin{array}{l}\text { Powder } \\
\text { fluidity, } \\
Q(\mathrm{~kg} / \mathrm{s})\end{array}$ & $\begin{array}{c}\text { Moisture } \\
\text { content and } \\
\text { tendency to } \\
\text { humidity, } \\
W(\%)\end{array}$ & $\begin{array}{c}\text { Tendency to } \\
\text { consolidation } \\
\text { and caking, } \\
C(\%)\end{array}$ \\
\hline Clay shale & $\begin{array}{l}\text { N } 0.1-5 \\
\text { N } 0.2-80 \\
\text { N } 0.3-12\end{array}$ & 0.17 & 1.02 & 2.03 \\
\hline Zeolite & $\begin{array}{l}\text { N } 0.1-10 \\
\text { N } 0.2-75 \\
\text { N } 0.3-15\end{array}$ & 0.16 & 4.5 & 0.3 \\
\hline Perlite & $\begin{array}{l}\mathrm{N} 0.1-10 \\
\mathrm{~N} 0.2-75 \\
\mathrm{~N} 0.3-15\end{array}$ & 0.14 & 0.7 & 0 \\
\hline Zeolite + Clay shale & $\begin{array}{l}\text { N } 0.1-7 \\
\text { N } 0.2-75 \\
\text { N } 0.3-12\end{array}$ & 0.16 & 3.5 & 1.5 \\
\hline Zeolite + Perlite & $\begin{array}{l}\text { N } 0.1-10 \\
\text { N } 0.2-75 \\
\text { N } 0.3-15\end{array}$ & 0.15 & 2.2 & 0.1 \\
\hline $\begin{array}{c}\text { Zeolite + Clay shale } \\
+ \text { Perlite }\end{array}$ & $\begin{array}{l}\text { N } 0.1-7.5 \\
\text { N } 0.2-78 \\
\text { N } 0.3-14\end{array}$ & 0.16 & 1.3 & 0 \\
\hline
\end{tabular}

The data of the table show that zeolite is characterized with lower ability of consolidation and caking but with comparatively high moisture adsorption compared to perlite and clay shale, while after mixing of clay shale, zeolite and perlite the moisture adsorption ability increases noticeably.

\section{Conclusions}

Thus, composite powders of zeolite, perlite and clay shale the dispersity of which is $200-250 \mu$ are characterized with low moisture adsorption ability, as well as, low consolidation and caking ability or with high performance properties. 
Thermogravimetric analysis and pilot tests carried out by us for determination of fire-extinguishing ability of such powders proved that they are characterized with high fire-extinguishing ability.

Thus, on the basis of the researches carried out by us we can conclude that zeolite, perlite and clay shale can be used for production of non-halogen, ecologically clean, composite fire-extinguishing powders, which does not require the following expensive chemical processing and modification with halogeninclusive hydrofobizative additives and are characterized with high performance properties, as well as, high fire-extinguishing ability.

\section{References}

[1] Gurchumelia, L., Baliashvili, G., Bejanov, F. \& Sarjveladze, N., Development of novel composite fire-extinguishing powders on the basis of mineral raw materials. Modelling, Monitoring and Management of Forest Fires 2008. First International Conference, University of Castilla - La Mancha, Spain. WIT Transaction on Ecology and the Environment, Vol. 119, 2008 WIT Press. pp. 61-67.

[2] Fire Extinguishing Powders. Nomenclature of indexes. GOST 4.107-83. Normative Documents, 0-1.ru, Russia, 1995, http://www.0-1.ru/law/default.asp?doc=/gost/4_107-83

[3] Baratov, A.N. \& Vogman, L.P., Fire extinguishing powder compositions. Stroyizdat, Moscow, 1982.

[4] Tardos, G.I., Application to caking of fine crystalline powders. Powder Handling and Processing. 8.3, pp. 215, 1996.

[5] Tardos, G.I., Khan, I.M. \& Mort P.R., Critical parameters and limiting Conditions in Binder Granulation of fine powders. Powder Technology, 94, pp. 245-258, 1997.

[6] Schreyer, E., Palrer, S., Caking of powder mixtures of crystalline and amorphous solids. Nestle Product Technology Center, Germany, PARTE C, 2007.

[7] Talu, I., Tardos, G.I. \& Van Ommen, J.R., Use of Stress Fluctuations to monitor wet granulation of powders of powders. Powder Technology, Vol. 117, pp. 149-162, 2001.

[8] Hydrophobe additive. Encyclopedia of Oil and Gas, http://www.ngpedia.ru/id009157p3.html 